\title{
Factors Affecting the Audit Delay and Its Impact on Abnormal Return in Indonesia Stock Exchange
}

\author{
Syarifa Yunindiah Lestari ${ }^{1} \&$ Muhammad Nuryatno ${ }^{1}$ \\ ${ }^{1}$ Accounting Doctoral Program in Economics, Faculty of Economics and Business, University of Trisakti, \\ Indonesia \\ Correspondence: Priyono, Graduate Program Master of Management, University Bina Darma, Palembang, \\ Indonesia. Tel: 812-1697-4878. E-mail: priyono.unu_sidoarjo@yahoo.com
}

Received: December 13, 2017

Accepted: January 2, 2018

Online Published: January 5, 2018

doi:10.5539/ijef.v10n2p48

URL: https://doi.org/10.5539/ijef.v10n2p48

\begin{abstract}
This study aims to study the phenomenon of audit delay that still Occurs in various companies in Indonesia Stock Exchange, Thus affecting the decision of the users of financial statements. This study secondary uses of data in 2009-2015 from 20 companies selected by purposive sampling method, which is to determine the company as a sample according to research needs. This research found that firm size (X1), leverage (X3), and audit opinion (X5) have the significant effect on the audit delay of the company in Indonesia Stock Exchange. While the variable profitability (X2) and reputation audit (X4) have no significant effect on audit delay in companies listed on Indonesia Stock Exchange. Audit delay (Y) does not affect stock price fluctuations, so it does not have a significant impact on the company's abnormal return (AR) on the Indonesia Stock Exchange.
\end{abstract}

Keywords: agency theory, auditing, and audit delay

\section{Introduction}

This research aims to study the audit delay phenomena that occur in the company in the Indonesia Stock Exchange. Phenomena audit this delay may affect the decision-making process of investors and users of financial statements of the company. In this era of the computerized accounting system, these phenomena should no longer occur at the company in the Indonesia Stock Exchange, as the online-based computerized system automatization very helpful in preparing the financial statements, as well as assist in conducting the audit process within the time specified. This research was motivated by research to study the factors that affect audit delay once the audit delay analyze the impact of the abnormal returns of companies in Indonesia Stock Exchange.

Some studies previous audit delay is a reference of this study, the research done by Iskandar and Trisnawati (2010), Shulthoni (2013), Puspitasari and Latrini (2014), Suryanto (2016), Puspitasari and Sari (2012). Empirically known that audit delay is influenced by several variables, namely; (A) variable firm size or the value of assets owned by the company, are used in research and Wiratmaja Haryani (2014). (B) Variable profitability or the growth rate of operating profit, used in research Rachmawati (2008), (c) the variable leverage or the ratio of the amount of debt to own capital, are used in research and Wirakusuma Angruningrum (2013). (C) Variable auditor reputation with big-four categories and non-big-four, used in research Lucyanda and Nura'ni (2013). (D) Variable audit opinion or the results of the auditor's assessment of the fairness of the financial statements, are used in research Kartika (2009).

Phenomena audit delay is a concern to users of financial statements, especially investors who need information audited financial statements to make decisions on the Stock Exchange. This has to be considered, so that this important study analyzed by measuring two phases: the first phase of analyzing the effect of variables that affect audit delay, and the second stage to analyze the influence audit delay to the abnormal returns of companies on the Stock Exchange.

Phenomena related to the audit delay referred to above, the Permasyng principal need to be assessed in this study were; (a) How the effect of variable firm size audit delay in the Indonesia Stock Exchange? (b) How the variables influence the profitability of the audit delay in the Indonesia Stock Exchange? (c) How the variables influence the reputation of the auditor to audit delay in Stock Exchange Indonesia? (d) How the variables influence the audit opinion to audit delay in the Indonesia Stock Exchange? and (e) How the variables influence 
audit delay of the abnormal returns of companies in Indonesia Stock Exchange?

Finally, this study is expected to be useful for (a) contribute to the development of science, especially in relation to the audit delay on the Stock Exchange, (b) provide feedback to the company management to pay attention to the significant variables influence on audit delay and its impact on abnormal returns, (c ) provide information to the Stock Exchange practitioners of the various factors related to the audit delay, and (d) a reference to the audit delay research company in Indonesia Stock Exchange.

\section{Theory and Hypothesis Development}

\subsection{Agency Theory}

This study this theory associated with the company's audit program mainly due to the contractual relationship between the parties as the principal owner of the company and as a management agent who manages the company to meet the interests of the principal. Agency theory as put forward Jensen and Meckling (1976), states that there is an agency relationship or contract between the principal owner of the company with the manager or agent, who commissioned to the agent to do a job running the company. The principal party gives full authority to the agent to run the company and make decisions according to expectations principal. In practice, the agency theory often led to conflicts between the agent and the principal with the case of asymmetric information, so that the principal needs to monitor that the decision carried out by the principal agent liking. One form of control by the principal is through auditing by an independent party and immediately reported the results of the audit on time or delayed,

\subsection{Auditing}

This study deals with the auditing activities undertaken by the company in the Indonesia Stock Exchange, with a view to present the financial statements on time and meet the applicable accounting standards. Generally stated that auditing is as an act of collecting and evaluating the evidence regarding various economic events (information) in order to determine and report the degree of correspondence between assertions-assertions (information) with the criteria that have been set. Therefore, to maintain the quality of the audit, the auditor relation is a way that can be done to maintain the independence, objectivity, and professionalism of the auditors (Mautz \& Sharaf, 1961).

\subsection{Audit Delay $(Y)$}

The financial statements required by various parties for the benefit of decision-making, so that timely submission of financial statements and accuracy becomes very important. Empirically proven that the submission of financial reports influence the decision of investors in the capital market, because the financial statements describe the overall achievement of the performance and future prospects of the company.

This is where the importance of the company's management and the auditors to work together to meet the target time of submission of financial statements. The delay in presenting the financial statements will impact the market reaction and the investors in the capital market, so a lot of research trying to find the factors that cause the audit delay, so as to find a solution to address the audit delay. Research audit delay are various factors that are considered influential on audit delay, has been done before by Haryani and Wiratmaja (2014), Aryaningsih and Budiartha (2014), Aditya and Nisykurlillah (2014), Ariyani and Budiartha (2014), Saemargani and Mustikawati ( 2015), and of the Son and Sukirman (2014).

\subsection{Effect of Firm Size (X1) to Audit Delay}

The company that has total assets greater will complete the audit longer than the company had total assets of smaller, This is mainly due to the number of samples to be used increasingly large and require audit procedures relatively long (Puspitasari \& Sari, 2012). Results of a previous study conducted by Puspitasari and Latrini (2014) and Haryani and Wiratmaja (2014), stating that the firm size significantly influences audit delay. Based on this view, this research put forward the hypothesis $\mathrm{H} 1$ of the following:

H1: Firm size positively affects audit delay in the Indonesia Stock Exchange.

\subsection{Influence Profitability (X2) to Audit Delay}

Research Puspitasari and Sari (2012) found that profitability and significant positive effect on audit delay. This happens because the higher the achievement of the company's profitability, the more time required by the auditors to ensure financial statement figures relating to the achievement of profitability, so tend to use time and audit procedures are relatively longer. It is natural that the opinion given by the auditors require moral consequences and accountability to users of financial statements on the Stock Exchange. 
Other research on the influence audit delay profitability has been done by Rachmawati (2008) and Suryanto (2016), and found that profitability significantly influences audit delay the company on the Stock Exchange.

Based on this view, this research put forward the hypothesis $\mathrm{H} 2$ of the following:

H2: The level of achievement of profitability and significant positive effect on audit delay in the Indonesia Stock Exchange.

\subsection{Effect of Leverage (X3) on Audit Delay}

Research Utami (2006) and Lucyanda and Nura'ni (2013) to fine that leverage significant effect on audit delay. This was largely due to the use of debt increases caused the audit process becomes longer since it takes several activities related to audit and confirmation of the amount of the debt that has contributed to audit delay.

Based on this view, this research put forward the hypothesis $\mathrm{H} 3$ as follow:

H3: The level of leverage and significant positive effect on audit delay in the Indonesia Stock Exchange.

\subsection{Reputation Influence Auditor (X4) to the Audit Delay}

Reputation has a significant impact on the audit report as fine delay in Anisykurlillah study (2014), Ariyani and Budiartha (2014). This was mainly caused by a reputable auditor tend to be more detail in conducting the audit process, so often experience delays in the presentation of the audit report, especially against companies that have less accounting data structure supported by technology-based information systems.

Based on empirical conditions and reference to these findings, this study proposes the following hypothesis $\mathrm{H} 4$ :

H4: Reputation audit positive and significant impact on audit delay in the Indonesia Stock Exchange.

\subsection{Effect of Audit Opinion (X5) to the Audit Delay}

Research Utami (2006), Aryaningsih and Budiartha (2014) found that the audit opinion significantly influences audit delay. This is mainly due to the unqualified opinion need to consider several conditions, so that when companies face less qualified position, it is necessary to process more detailed audit to discover supporting evidence to meet the requirement as unqualified.

Based on the opinions and references on these results, the study hypothesis $\mathrm{H} 5$ propose the following:

H5: Audit opinion is a positive and significant impact on audit delay in the Indonesia Stock Exchange.

\subsection{Audit Delay Influence on the Abnormal Return (AR)}

The reaction between the capital markets is reflected in the abnormal return is the difference between the return of (Ri) with a market return ( $\mathrm{Rm})$ as Shulthoni (2013). The reaction of investors in the capital market, among others because of the financial statements reported by the company, so the sooner the report presented the faster the reaction.

Instead, presentation of financial statements has been delayed will have an impact on the reaction of stakeholders to the financial statements. Return market (Ri) as the quotient between changes in stock prices (from period t-1 to period t) with the share price in the previous period (t-1). While the market return (Rm) as the comparison between changes in JCI (from period t-1 to period t) with JCI previous period (period t-1).

The study, using abnormal return as a factor that is affected by the delayed audit conducted by Shulthoni (2013) and found that audit delay significant effect on abnormal returns of companies on the Stock Exchange. Based on these considerations, the research hypothesis H6 propose the following:

H6, Audit delay significant effect on abnormal returns of companies in Indonesia Stock Exchange.

\subsection{Framework}

The study analyzed the factors that affect audit delay (Y), and assess their impact on the abnormal return (AR) company on the Stock Exchange. Factors affecting the audit delay is identified in accordance with the approach of theory, empirical condition and results of previous studies, which consists of firm size (X1), profitability (X2), leverage (X3), auditor reputation (X4) and audit opinion (X5).

Firm size is based on the size of the overall asset value at the end of the period corresponding year-end financial statements. Profitability rated based on achievement of operating profit as a result of the company's core business. Leverage as a result of the comparison between the amount of debt that is used compared with their own capital at the end of the accounting period. Reputation is a measure of the magnitude of the auditor's audit were grouped on big-four and non-big-four. The audit opinion as a result of the audit in accordance with the level of fairness of the financial statements of the company, which consists of an unqualified opinion and the 
other opinion.

The relationship between these variables, operational framework described in the following:

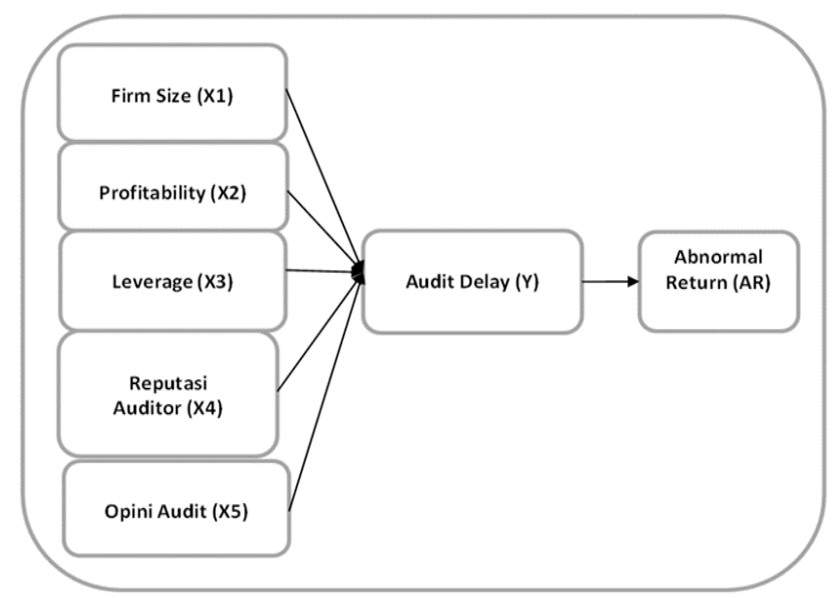

Figure 1. Factors affecting audit delay and the impact on the abnormal return

\section{Methodology}

\subsection{Sample Selection}

The sample used in the study using the method purposive sampling which determines the sample is considered to explain the phenomena studied. The number of companies which have as many as 20 active issuers whose shares are traded on the Stock Exchange in the period from 2009 to 2015, so this research using observations of 140-year-enterprises.

\subsection{Model Analysis}

To test this research hypothesis using a regression equation Model 1 and Model 2, while the audit delay effect against abnormal return using the following three models:

Hypothesis factors that affect audit delay

$$
\begin{gathered}
Y_{i t}=\beta_{0}+\beta_{I} X 1_{i t}+\beta_{2} X 2_{i t}+\beta_{3} X 3_{i t}+\beta_{4} X 4_{i t}+\beta_{5} X 5_{i t}+e_{i t} \\
Y_{i t}=\beta_{0}+\beta_{1} X 1_{i t}+\beta_{2} X 2_{i t}+\beta_{3} X 3_{i t}+\beta_{5} X 5_{i t}+e_{i t}
\end{gathered}
$$

Hypothesis audit delay effect against abnormal return

$$
A R_{i t}=\beta_{0}+\beta_{1} Y_{i t}+e_{i t}
$$

Where: $\mathrm{Y}=$ audit delay, $\mathrm{X} 1=$ firm size, $\mathrm{X} 2=$ profitability, $\mathrm{X} 3=$ leverage, $\mathrm{X} 4=$ the reputation of auditors, and $\mathrm{X} 5=$ audit opinion, $\mathrm{AR}=$ abnormal return, $\beta 0=$ constant, $\beta 1 \ldots \beta 5=$ regression coefficient, $\mathrm{e}=$ error ,

\subsection{Definitions and Measurement Variables}

The variables used in this study is defined and measured as follows:

a) Audit delay (Y), the time of completion of the audit of annual financial statements, base on measured the time between the closing date of December 31 books to an independent auditor's report recorded in the financial statements presented by the auditor. Measurement of these variables have been used in research; Son and Son (2016), Praptika and Rasmini (2016), Trisnawati and Alvin (2014), Rustiarini and Sugiarti (2013), And Abidin Ahmad (2008), Habib and Bhuiyan (2011), and Lee and Jahng (2008).

b) Firm size (X1), is the number of assets owned by the company, measured by the logarithm of total assets. Measurement of these variables has been used in research Lee and Jahng (2008), Ahmad and Abidin (2008).

c) Profitability (X2), operating profit growth rate between time, measured by the growth in operating profit to operating profit of period $\mathrm{t}$ period (t-1). Measurement of these variables has been used by the researchSumartini and Widhiyani (2014), Habib and Bhuiyan (2011).

d) Leverage (X3), the ratio between the amount of debt to the amount of their own capital. Measurement of these variables has been used bySumartini and Widhiyani (2014). 
e) Reputation auditor (X4), the reputation of the Public Accounting Firm (KAP), which audited financial statements are measured using dummy variables, namely the big-four accounting firm $=1$, others $=0$. Measurement of these variables has been used in researchTrisnawati and Alvin (2014), Kartika (2009).

f) Audit opinion (X5), the opinion given by the independent auditors for the fairness of the financial statements of the company, measured using dummy variables, namely the company received unqualified opinion $=1$ and the other $=0$. These variable measurements have been used in research Son and Sukirman (2014).

g) Abnormal return is the difference between the stock return (Ri) with a market return ( $\mathrm{Rm})$. Ri is obtained from the difference between the stock price at period $\mathrm{t}$ minus the stock price period $(\mathrm{t}-1)$ divided by the stock price period $(\mathrm{t}-1)$. While the market return $(\mathrm{Rm})$ is obtained from the difference between the stock price index or CSPI CSPI period minus the period $\mathrm{t}(\mathrm{t}-1)$ divided by JCI period $(\mathrm{t}-1)$. Measurement of these variables has been used in research Shulthoni (2013).

\section{Results and Discussion}

\subsection{Descriptive Statistics}

Research data variables used in the analysis model, structured in groups of minimum, maximum, mean, or average, and standard deviation magnitude as Table 1 below. For example, to audit the variable delay, the data distributed in the range of a minimum of 24 and maximum of 135, with an average value of 79.06 and a standard deviation of 16.88. And so on for the independent variables X1, X2, X3, X4, X4 and AR below.

Table 1. Descriptive statistics

\begin{tabular}{lccccc}
\hline Variable & $\mathrm{N}$ & Minimum & Maximum & Mean & Std. Deviation \\
\hline Y & 140 & 24.00 & 135.00 & 79.06 & 16.88 \\
X1 & 140 & 6.27 & 11.37 & 9.70 & 1.17 \\
X2 & 140 & -35.10 & 39.80 & 0.16 & 5.16 \\
X3 & 140 & -4.76 & 18.19 & 1.56 & 2.97 \\
X4 & 140 & 0.00 & 1.00 & 0.35 & 0.48 \\
X5 & 140 & 0.00 & 1.00 & 0.63 & 0.48 \\
AR & 140 & -0.90 & 0.37 & -0.04 & 0.16 \\
Valid N (listwise) & 140 & & & & \\
\hline
\end{tabular}

Note. Y: audit delay, X1: firm size, X2: profitability, X3: leverage, X4: reputation audit; X5: opinion audit, AR: abnormal return.

\subsection{Correlation Analysis}

This analysis is used to supplement the results of the regression analysis in explaining the problems and test the hypothesis of this study. Person product moment correlation analysis was first put forward by Pearson (1904) stating that the correlation is demonstrating a degree of linear relationship between two or more variables. Correlation analysis was used to analyze the phenomenon of the relationship between the variables are interrelated as in Table 2 below.

Table 2. Correlation matrix

\begin{tabular}{rccccccc}
\hline & $\mathrm{Y}$ & $\mathrm{X} 1$ & $\mathrm{X} 2$ & $\mathrm{X} 3$ & $\mathrm{X} 4$ & $\mathrm{X} 5$ & $\mathrm{AR}$ \\
\hline $\mathrm{Y}$ & 1 & & & & & \\
$\mathrm{X} 1$ & $-.168^{*}$ & 1 & & & & \\
$\mathrm{X} 2$ & .014 & -.001 & 1 & & & \\
$\mathrm{X} 3$ & $.176^{*}$ & .093 & -.035 & 1 & 1 & & \\
$\mathrm{X} 4$ & .038 & -.012 & -.044 & -.038 & .161 & 1 & 1 \\
$\mathrm{X} 5$ & $.264^{* *}$ & -.048 & -.129 & -.085 & $.172^{*}$ & -.040 & \\
$\mathrm{AR}$ & -.137 & .005 & -.062 & -.067 & & & \\
\hline
\end{tabular}

* Correlation is significant at the 0.05 level (2-tailed).

** Correlation is significant at the 0.01 level (2-tailed).

Note. Y: audit delay, X1: firm size, X2: profitability, X3: leverage, X4: reputation audit; X5: opinion audit, AR: abnormal return.

At the $\mathrm{Y}$ column indicates that the correlation variable $\mathrm{Y}$ with $\mathrm{X} 1$ and $\mathrm{X} 3$ variables significant at 0:05 or 5\% level (two-tailed), variable Y with X5 correlation significant at the level of 0:01 or 1\%, and other variables are not significantly correlated with the variable Y. column 2 onwards showed a correlation between X1, X2, X3, X4, 
and X5 showed a significant correlation does not indicate that there is no multicollinearity between the independent variables or meet the assumptions of linear regression.

\subsection{Hypothesis Test Calculation Results}

The result of the calculation as in Table 3 below that prove the hypothesis about the factors that affect audit delay and its impact on abnormal returns.

\subsection{Hypothesis Factors That Affect Audit Delay}

Variable X1 firm size or negatively affect audit delay with regression coefficients -2507 and sig.0.032 ** at 0:05 or 5\% level. This means that the bigger the company, the lower the level of audit delay between companies. This condition occurs mainly due to the company having a larger-scale businesses tend to have a US-based online information system, thereby assisting in the audit process and minimize the possibility of audit delay.

Variable X2 profitability or positive and significant impact on audit delay with coefficients 0189 and sig. 0476 which means that this variable does not affect significant audit delay. This is mainly due to the achievement of profitability is not a constraint on the audit so that audit delay is not affected.

$\mathrm{X} 3$ variable leverage or positive and significant impact on audit delay with regression coefficient 1.238 and sig. $0008 * * *$. This shows that the higher the number the use of debt to total capital itself, the longer the required audit process and lead to a high audit delay experienced by the company.

Variable reputation or X4 audit and no significant positive effect on audit delay with regression coefficient 0.035 and sig. 0990, which means that this variable does not have a significant impact on the audit delay. This occurs because the auditor has had a structured audit program and have been considering companies that will be audited and prepare the number and quality of auditors who will conduct the audit assignment, so the big-four auditor or non-big-four does not affect the audit delay.

Audit opinion or X5 positive and significant impact on audit delay with regression coefficients 9784 and sig. $0001 * * *$ which means that these variables have a significant impact on the audit delay. This happens because unqualified opinion requires several criteria, so that the company could potentially gain unqualified audit opinion tends to delay. In contrast to companies that obtain other audit opinion, audit delay tends to be smaller.

\subsection{Hypothesis Audit Delay Effect Against Abnormal Return}

Variable delay or $\mathrm{Y}$ influence on audit and no significant negative abnormal return to variable or AR with regression coefficients -0001 and sig. 0107 , which means that this variable does not have a strong influence on the abnormal return achieved by the company in the Stock Exchange. This happens mainly because market participants or investors in the Stock Exchange consider many issues in its investment decisions, so that audit delay does not significantly influence the company stock price changes. The decision of investors in the Stock Exchange is not only based on financial statement information presented by an independent auditor, but also use other information that can be accessed through the Internet and external environmental conditions affecting the company, such as changes in exchange rates, balance of payments.

Table 3. Factors affecting audit delay

\begin{tabular}{|c|c|c|c|c|c|c|c|}
\hline \multicolumn{8}{|c|}{$\begin{array}{l}Y_{i t}=\beta_{0}+\beta_{I} X 1_{i t}+\beta_{2} X 2_{i t}+\beta_{3} X 3_{i t}+\beta_{4} X 4_{i t}+\beta_{5} X 5_{i t}+e_{i t} \\
Y_{i t}=\beta_{0}+\beta_{I} X 1_{i t}+\beta_{2} X 2_{i t}+\beta_{3} X 3_{i t}+\beta_{5} X 5_{i t}+e_{i t} \\
A R_{i t}=\beta_{0}+\beta_{I} Y_{i t}+e_{i t}\end{array}$} \\
\hline \multirow[t]{2}{*}{ Variable } & \multirow[t]{2}{*}{ Predict } & \multicolumn{2}{|c|}{ Model-1: dependnet var.Y } & \multicolumn{2}{|c|}{ Model-2: dependnet var.Y } & \multicolumn{2}{|c|}{ Model-1: dependnet var. AR } \\
\hline & & Coeff. & Sig. & Coeff. & Sig. & Coeff. & Sig. \\
\hline (Constant) & & 95.250 & $0.000 * * *$ & 95.259 & $0.000 * * *$ & 0.065 & 0.305 \\
\hline $\mathrm{X} 1$ & - & -2.507 & $0.032 * *$ & -2.507 & $0.031 * *$ & & \\
\hline $\mathrm{X} 2$ & + & 0.189 & 0.476 & 0.189 & 0.474 & & \\
\hline $\mathrm{X} 3$ & + & 1.238 & $0.008 * * *$ & 1.238 & $0.008 * * *$ & & \\
\hline $\mathrm{X} 4$ & + & 0.035 & 0.990 & & & & \\
\hline $\mathrm{X} 5$ & + & 9.784 & $0.001 * * *$ & 9.789 & $0.001^{* * *}$ & & \\
\hline $\mathrm{Y}$ & - & & & & & -.001 & .107 \\
\hline Adj-R2 & & 0.110 & & 0.117 & & 0.045 & 0.012 \\
\hline F-Statistic & & 4.449 & & 5.603 & & 3.172 & 2.636 \\
\hline Prob F-Statistic & & 0.001 & & 0.000 & & 0.026 & 0.107 \\
\hline Total Observation & & 140 & & 140 & & 140 & 140 \\
\hline
\end{tabular}

*** Significant at the a level of 1 percent, ** Significant at the a level of 5 percent, *Significant at the a level of 10 percent.

Note. Y: audit delay, X1: firm size, X2: profitability, X3: leverage, X4: reputation audit; X5: opinion audit, AR: abnormal return. 


\subsection{Discussion Hypothesis}

Model 1 as the result of the hypothesis test calculations in Table 3 shows that the leverage variable or variables X3 and X5 audit opinion or a positive and significant impact on audit delay at 0:01 or level of 1\%, which means that the results of these calculations support the hypothesis in this study. Variable firm size or X1 indicates that the size of the audited company a significant negative effect on audit delay at 0:05 or 5\% level, which means that the results of these calculations support the hypothesis in this study. Variable and variable profitability or X2 or $\mathrm{X} 4$ auditor reputation and no significant positive effect on audit delay so that the results of these calculations do not support the hypothesis in this study.

Model 2 is used to test the consistency of the effect of independent variables to the audit delay by ignoring one of the variables X4 reputation audit or an insignificant effect, but the result is consistent with the Model 1 . Variable or X1 firm size, leverage or X3 and X5 audit opinion or a significant effect on audit delay, while the profitability or $\mathrm{X} 2$ variables did not significantly affect audit delay.

Model 3 shows the audit delay variable (Y) is not significant to the variable abnormal return (AR), which means that the hypothesis test calculation results do not support the hypothesis in this study. These phenomena occur mainly due to the decision of investors in the capital market is not only based on the audit report but also consider various external environmental factors associated with the company, so that audit delay no significant effect on the share price on the Stock Exchange and the abnormal return (AR) did not change significantly ,

\section{Conclusion}

Based on the results and discussion of hypothesis testing, it can be concluded: (a) Firm size (X1) a significant negative effect on audit delay at the level of 0:05 or 5\%, which means that the size of the company's capacity greater tends to occur audit delay lower and lower, because the company has an online-based information system that helps the audit process. (B) Profitability (X2) and no significant positive effect on audit delay, especially because the audit process not only pay attention to the level of profitability of the company, but the overall audit the transactions that make up the fairness of the financial statements. (C) Leverage (X3) positive and significant impact on the level of 0.01 or $1 \%$, which means that the greater the amount of debt to equity in the company, the greater the likelihood of the company they audit delay. This occurs because the audit process requires more detail than companies that have a number of relatively less debt. (D) Reputation audit (X4) not significant effect on audit delay, especially because of the size of the big-four auditor or non-big-four has a standard audit, so they would not affect the audit delay. (E) audit opinion (X5) positive and significant impact on audit delay at the level of 0:01 or $1 \%$, this happens because the audit opinion requires the terms of fairness, so that companies that obtain opinions unqualified tends to audit delay, then companies that acquire other opinion, (F) Audit delay (Y) and no significant negative effect on the abnormal return (AR) company on the Stock Exchange,

\subsection{Implications of the Study}

Given this research, the implications on the management's discretion are important considers a variety of factors that caused the audit delay. This study has shown that the independent variable firm size (X1), leverage (X3), and audit opinion (X5) has a significant contribution to the company's audit delay on the Stock Exchange.

\subsection{Research Limitations}

This study has limitations, especially because it only uses secondary data that is based on financial statement information presented by each issuer observed during some periods. To complete this study, it is suggested that future research using primary data and secondary data all at once, so that the results of the analysis can include a variety of things in a comprehensive manner related to the audit delay that occurred in the company in the Indonesia Stock Exchange.

\section{References}

Aditya, A. N., \& Anisykurlillah, I. (2014). Factors Affecting Against Audit delay. Accounting Analysis Journal, 3(3), 334-342.

Ahmad, A. C., \& Abidin, S. (2008). Audit delay Of Listed Companies: A Case of Malaysia. International Business Research, 1(4), 32-39.

Angruningrum, S., \& Wirakusuma, M. G. (2013). The Influence of Profitability, Leverage, Complexity of Operations, Reputation of Kap and Audit Committee At. Audit delay. E-Journal of Accounting Udayana University, 5(2), 251-270.

Ariyani, N. N. T. D., \& Budiartha, I. K. (2014). The Influence of Profitability, Company Size, Complexity of Company Operations and Reputation of the Lag on the Lag Aud Report on Manufacturing Companies. 
E-Journal of Accounting Udayana University, 8(2), 217-230.

Aryaningsih, N. N. D., \& Budiartha, I. K. (2014). Influence of Total Assets, Level of Solvency And Audit Opinion In Audit delay. E-Journal of Accounting Udayana University, 7(3), 747-760.

Habib, A., \& Bhuiyan, M. B. U. (2011). Audit firm industry specialization and the audit report lag. Journal of International Accounting, Auditing, and Taxation, 20(1), 32-44. https://doi.org/10.1016/j.intaccaudtax.2010.12.004

Haryani, J., \& Wiratmaja, I. D. N. (2014). The Influence of Corporate Kuran, Audit Committee, Implementation of International Financial Reporting Standards and Public Ownership on Audit delay. E-Journal of Accounting Udayana University, 6(1), 63-78.

Iskandar, M. J., \& Trisnawati, E. (2010). Factors Affecting Lag Lag Audits on Companies Listed on the Indonesia Stock Exchange. Journal of Business and Accounting, 12(3), 175-186.

Kartika, A. (2009). Factors Affecting Delay Audits In Indonesia (Empirical Study of Lq 45 Companies Listed In The Jakarta Stock Exchange). Journal of Business and Economics (Jbe), 16(1), 1-17.

Ckling, W. H. (1976). Theory of The Firm: Man Age Rial Behavi or, Agency Costs, and Ownership Structure. Journal of Financial Economics, 3(4), 305-360. https://doi.org/10.1016/0304-405X(76)90026-X

Lee, H. Y., \& Jahng, G. J. (2008). Determinants of Audit Report Lag: Evidence From Korea - An Examination Of Auditor-Related Factors. The Journal of Applied Business Research, 24(2), 27-44.

Lucyanda, J., \& Nura'ni, S. P. (2013). Testing Factors Affecting Audit delay. Journal of Accounting \& Auditing, $9(2), 128-149$.

Mautz, R. K., \& Sharf, H. A. (2006). The Philosophy of Auditing. American Accounting Association.

Pearson, K. F. R. S. (1904). Report On Certain Enteric Fever Inoculation Statistics. Applied Mathematics, University College, London, 1242-1247.

Praptika, P. Y. H., \& Rasmini, N. K. (2016). Effect of Tenure Audit, Auditor Substitution And Financial Distress in Audit Delays at Consumer Goods Company. E-Journal of Accounting Udayana University, 15(3), 2052-2081.

Puspitasari, E., \& Sari, A. N. (2012). Influence of Company Characteristics Against Duration of Audit Completion Time (Audit delay) on Manufacturing Company Listed In Indonesia Stock Exchange. Journal of Accounting \& Auditing, 9(1), 31-42.

Puspitasari, K. D., \& Latrini, M. Y. (2014). Influence of Company Size, Subsidiary, Leverage and Cap Size Against. E-Journal of Accounting Udayana University, 8(2), 283-299.

Putra, A. B. S., \& Sukirman. (2014). Auditor Opinion, Gain or Loss of Current Year, Switching Auditor in Predicting Audit Delay. Accounting Analysis Journal, 3(2), 187-193.

Putra, P. G. O. S., \& Putra, I. M. P. D. (2016). Company Size to Moderate the Influence of Auditor Opinion, Profitability and Debt to Equity Ratio to Audit Delay. E-Journal of Accounting Udayana University, 14(3), 2278-2306.

Rachmawati, S. (2008). The Influence of Internal and External Factors Companies to Audit Delay and Timeliness. Journal of Accounting and Finance, 10(1), 1-10.

Rustiarini, N. W., \& Sugiarti, N. W. M. (2013). Effect of Auditor Characteristics, Audit Opinion, Tenure Audit, Auditor Substitution In Audit delay. Journal of Accounting and Human Sciences, 2(2), 657-675.

Saemargani, F. I., \& Mustikawati, R. I. (2015). Influence of Company Size, Age of Company, Profitability, Solvency, Cap Size, and Auditor Opinion to Audit delay. Nominal Journal, 2(1), 1-15.

Shulthoni, M. (2013). Determinants of Audit Delays and Their Influence on Investor Reaction (Empirical Study of Companies Listed In IDX 2007-2008). Journal of Actual Accounting, 2(1), 9-18.

Sumartini, N. K. A., \& Widhiyani, N. L. S. (2014). The Influence of Audit Opinion, Solvency, Size of the Kap and Profit and Loss in Audit Report Lag. E-Journal of Accounting Udayana University, 9(1), 392-409.

Suryanto, T. (2016). Audit delay and Its Implication for Fraudulent Financial Reporting: A Study of Companies Listed on the Indonesian Stock Exchange. European Research Studies, 19(1), 18-31.

Trisnawati, E., \& Alvin, A. (2014).Influence of Total Assets, Industrial Type, KAP Size and Type of Accountant Opinion Against Timeframe of Completion of AUDIT Process (Audit delay) on Companies Listed in 
Indonesia Stock Exchange (BEI) Year 2006-2007. Accounting Journal, 10(2), 113-134.

Utami, W. (2006). Determinant Analysis Audit delay Empirical Assessment at the Jakarta Stock Exchange. Bulletin Research, 9(1), 19-31.

\section{Copyrights}

Copyright for this article is retained by the author(s), with first publication rights granted to the journal.

This is an open-access article distributed under the terms and conditions of the Creative Commons Attribution license (http://creativecommons.org/licenses/by/4.0/). 